\title{
ANALYSIS OF ZERO RUPIAH DOWN PAYMENT HOUSE POLICY FORMULATION FOR LOW INCOME COMMUNITIES IN DKI JAKARTA
}

\author{
Harry Nenobais* \\ Administration Science Study Program \\ Universitas Prof. Dr. Moestopo (Beragama) \\ Asnawi \\ Administration Science Study Program \\ Universitas Prof. Dr. Moestopo (Beragama) \\ *Correspondence: harynenobais@dsn.moestopo.ac.id
}

\section{ARTICLE INFO}

\section{Article History:}

received: $19 / 09 / 2021$

revised: $20 / 10 / 2021$

accepted: $31 / 10 / 2021$

\section{Keywords:}

intellectual capital, governance, green

building, market, DKI Jakarta

DOI:

https://doi.org/10.32509/mirshus.v1i2.20

\section{ABSTRACT}

This study describes the public policies of the DKI Jakarta Provincial Government on housing assistance for law-Income Communities. DKI Jakarta as the center of Government and economy attract people to come to the city. The scarcity and the high price of land in DKI Jakarta factors into the number of Low-Income Communities in the city who struggle to own housing/property. The study aims to analyze the policy formulation of DKI Jakarta Provincial Government on the assistance in providing decent housing needs the policy formulation of the DKI Jakarta Provincial Government for assistance in providing decent housing needs for Low-Income Communities. The research uses descriptive qualitative methods by using primary and secondary data. Data and information are obtained through interviews with the actors involved in the process of policy formulation, surveys and taking photographs related to the Zero Rupiah Down Payment House and document that can support research. From the analysis, it is found in the formulation of the Zero Rupiah Down Payment House Program policy that there should be stronger legal basis and a set of wage margin for Low-Income Communities in DKI Jakarta as well as supervision in the implementation of the program so that it is targeted to the Low-Income community by paying attention to aspects of alignments to the community need. 


\section{INTRODUCTION}

The house is a primary human need that has a very important function for human survival as a protector from natural disturbances from the weather and other living creatures. The house is not only a building (structural), but also a residence that meets the requirements of a decent life, viewed from various aspects of community life. Home can be understood as a place of refuge, to enjoy life, rest and have fun with family. Inside the house, residents get the first impression of their life in this world. The house must guarantee the interests of the family, namely to grow, give the possibility to live in association with its neighbors, and more than that, the house must provide peace, pleasure, happiness, and comfort in all the events of his life (Frick and Mulyani, 2006; Aminudin, 2007).

However, the increasing demand for housing in big cities has resulted in higher house prices. High house prices make it difficult to realize the dream of owning a house, especially for low-income people. Then population growth that is concentrated in urban areas is prone to giving rise to slum areas, both on the banks of railroads, and along rivers. This is because the fulfillment of housing needs is increasingly difficult to fulfill. From year to year the gap between the needs for housing supply still occurs, especially for low-income people due to low purchasing power or limited access to the housing finance system (Mangeswuri, 2016).

Therefore, the government needs to be present and play an active role in providing and facilitating the acquisition of houses for the community through the implementation of housing and settlement areas as well as community self-help. The provision and ease of acquisition of the house is a functional unit to ensure environmental sustainability in line with the spirit of democracy, regional autonomy, and openness in the life of society, nation and state.
In response to this, the DKI Jakarta Provincial Government has made a policy for the zero rupiah down payment program for low-income communities in DKI Jakarta, namely in the form of Governor Regulation Number 104 of 2018 as a legal basis in implementing the zero rupiah Down Payment (DP) house program with credit or credit time. maximum repayment of 20 years.

Of course, this is good news for residents of DKI Jakarta who do not have a permanent home, especially the price of land in DKI Jakarta which is increasingly unaffordable for low-income people. The Zero Rupiah Downpayment House Samawa Program is a financing facilitation program by the DKI Jakarta Provincial Government to address the problem of home ownership. Through this program, the DKI Jakarta Provincial Government provides ownership financing facilities with a zero rupiah down payment scheme. By fulfilling the need for a light ownership scheme for DKI Jakarta residents to be able to have a decent place to live, it is expected to be able to improve the quality of life of the community.

However, in the implementation of the program, several difficulties and problems were encountered, namely: First, as a policy, of course this has received attention from various parties, such as according to city planning observer, Nirwono Joga, who said DKI Jakarta must be honest with the public regarding the zero rupiah down payment scheme. which comes from the DKI Jakarta APBD budget through a regional capital participation scheme, because a DP of 0 Rupiah means that the down payment for the DP is bailed out by the DKI Jakarta Regional Government, meaning that the prospective buyer is still charged with replacing the down payment at a later date. So it's not free DP. Second, there is no strong legal basis such as local regulations as a basis for optimally implementing the policy. Until now, the zero rupiah down 
payment house program is based on the Governor's Regulation, while the housing loan runs for 20 years, so it is feared that when there is a change of governor, the policy can be changed again. Third, in the zero rupiah down payment program, it is a vertical house and not a landed house. Due to the lack of land that can be used as a place to live. The house is intended for residents who earn $\mathrm{Rp}$ 4-7 million. This then makes the poor people disappointed. Fourth, in the implementation there are still some people who feel that the technical and administrative process is still slow to get the zero rupiah down payment house.

Some of the problems above have finally made the implementation of the zero rupiah down payment program policy for low-income people in DKI Jakarta based on Governor Regulation Number 104 of 2018 not yet run optimally so that the goal of the policy to provide housing for the poor who do not have a house has not been realized.

By using Mustopadidjaja's (2003) theory, there are two questions in this study, namely: (1) What is the process of policy formulation on the zero rupiah down payment program for low-income people in DKI Jakarta? (2) What are the aspects that influence the formulation of the zero rupiah down payment program for low-income people in DKI Jakarta?

\section{DISCUSSION}

Based on the research results of the zero rupiah down payment program for lowincome communities in DKI Jakarta based on Governor Regulation Number 104 of 2018, it was found: First. Assessment of the difficulty of low-income people owning houses in DKI Jakarta due to the continued increase in the number of residents and housing developers who are not in favor of low-income people with a very large down payment burden with requirements that are difficult to meet for the community so that the government needs to intervene to

\section{METHOD}

The paradigm used in this research is the constructivist paradigm. This paradigm aims to observe, describe, understand, and analyze the problematic phenomena that take place in the policy formulation of the zero rupiah down payment program for lowincome communities in DKI Jakarta. The research method used is qualitative, namely describing or explaining something as it is, the data obtained will be analyzed and described based on the discovery of facts in the field. The tools used in the study were cameras, recorders and in-depth interview guide sheets (Creswell, 2016).

Primary data sources In this study, it was obtained through interviews with the Governor of DKI Jakarta Province, DKI Jakarta Public Housing and Settlement Service, members of the DKI Jakarta DPRD, NGOs, housing observers and house users. Data collection techniques used in researching the formulation of a zero down payment house policy for low-income people in DKI Jakarta is an in-depth interview, observation, literature study and documentation study. Data analysis carried out at the time of data collection included three stages: data reduction, data display, and verification conclusion. In this study also used triangulation techniques (Neuman, 2006).

determine a pro-poor mechanism. providing housing for low-income people. However, the availability of land in Jakarta to be used as settlements is almost non-existent, although there is land that has not been developed but its status is already owned by private developers. Then the number of residents of Jakarta has exceeded the number of 13 million people. Second. Goal setting. The goal of the zero rupiah down payment program is to reduce the very high rate of homelessness and the results of the research show that down payment is one of the obstacles besides the availability of 
houses. Because we see a segment that needs help from the down payment side, because the problem of not having a house has many causes. Financing schemes are formulated by the government to reduce the burden on low-income people in meeting their housing needs, starting from loans with soft interest, long-term loans, partnerships with cooperatives or microfinance institutions, and policies that are oriented towards bureaucratic ease for low-income people. Third. Alternative formulation. To meet the housing needs of low-income communities can be grouped into two, namely the fulfillment of housing needs to be closer to the workplace and the fulfillment of housing needs for efforts to improve the community's economy can be realized in several strategic steps to expand public access to development resources and create opportunities for lower-level communities to participate in the development process, so that people can overcome backwardness and strengthen their economic competitiveness. (Gunawan, 1998: 146). One of the efforts that can be done is to form an economic body such as a cooperative to support the economy of the residents of the zero Rupiah downpayment house and revive the social life of the Zero Rupiah downpayment house residents. Fourth. In preparing the model in this study, the researcher used a schematic model. According to Elias M. Awad (1979: 10) a schematic model is a chart that describes the system elements and their interrelationships with each other. Here the elements are depicted in squares, and the flow of goods, information, and feedback is represented by arrows.

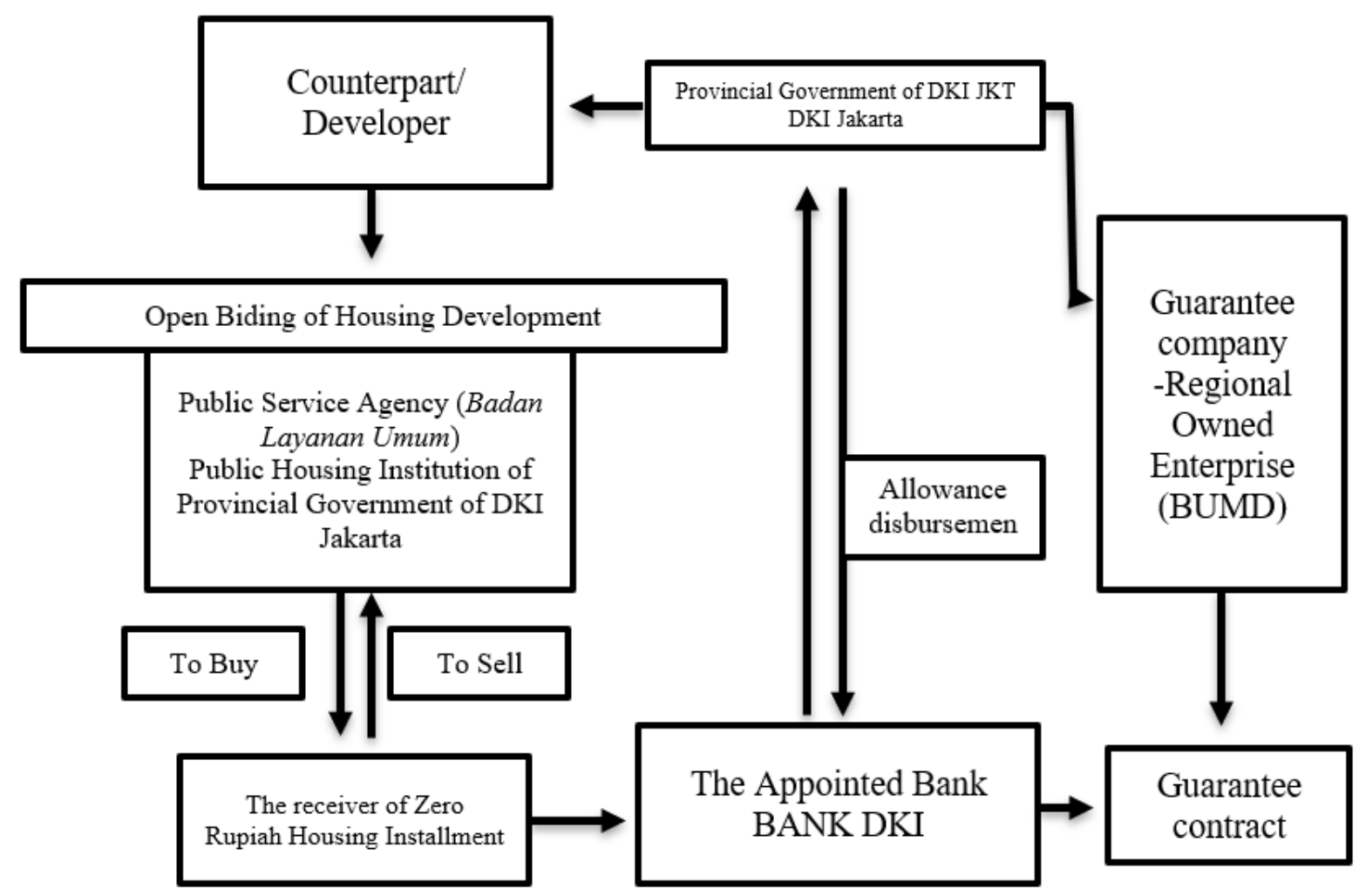

Picture 1. Zero Rupiah Downpayment Home Program Scheme and Premium Loans Source: Managed by Authors, 2021

Fifth. Determination of Criteria. In this study, researchers used 3 aspects that influenced the formulation of the Zero Rupiah DP home program policy, namely: 
a. Political Aspect: The zero Rupiah DP house program is a political promise for the governor (Anies Baswesdan) in the 2017-2022 gubernatorial election campaign. Therefore, as a priority program for the DKI Jakarta Provincial Government, one of them is the zero Rupiah down payment program as a result of the political promise of the regional head. Therefore, the zero Rupiah down payment program as a policy based on a political promise is included in the priority program of the DKI Jakarta Provincial Government. As a priority program of the DKI Jakarta Provincial Government, of course, this program must be targeted at low-income communities in DKI Jakarta. But in its implementation there are still many vacant units due to the tight selection carried out by the Housing Service in collaboration with the relevant Office and Bank DKI. As a political promise from the governor, the zero Rupiah down payment program is expected to overcome the backlog of home ownership in DKI Jakarta by implementing more effective and efficient procedures for low-income communities.

b. Economy Aspect: In the zero Rupiah DP house program, the DKI Jakarta Provincial Government has formed a UPT in its implementation so that the financial mechanism is managed by the BLUD. Community installments will be included in non-tax regional income so that the incoming money will be managed so that it does not burden the APBD every year for maintenance. With these managed funds, there should no longer be any maintenance fees charged to home consumers with zero down payment. The installment fee paid should include costs for maintenance so that it does not add to the community's burden by spending maintenance money. This means that the Provincial Government of DKI Jakarta must use the zero Rupiah down payment program as a policy that increases local revenue.

c. Law Aspect: To realize the governor's promise, the implementation of the zero Rupiah DP house program has the basis of Governor Regulation Number 108 of 2018 and Governor's Decree Number 855 of 2019. With regulations according to this, the zero Rupiah down payment policy can be changed as the governor of DKI Jakarta changes. Therefore, there must be a strong legal umbrella in the implementation of zero Rupiah down payment as according to Wibowo Edi (2004: 18) in the administration of local government, public policy and law have an important role.

Sixth. Alternative assessment. In dealing with home ownership in DKI Jakarta, the DKI Jakarta Provincial Government has 3 options for the people of DKI Jakarta including:

a. Social Service House

For the poor who have no income, a house belonging to the social service office is provided and even training is provided there.

b. Flats for Rent

For the lower class with a lowcost rental system

c. Zero Rupiah Installment House

Simple flat house for middle class community who have a fixed income and are able to pay monthly installments but cannot afford a down payment when buying a house. Meanwhile, the income limit for lowincome people applied by the DKI Jakarta Provincial Government is still too general to follow the Regulation of the Minister of Housing. The Provincial Government of DKI Jakarta must make a separate study on the income limit of low-income people in DKI Jakarta because it is not the same as the 
income of people in other areas. Seventh. Recommendation Formulation. The zero Rupiah down payment program is very beneficial for low-income people because people feel that it is easier for them to own a house with a down payment paid in advance by the DKI Jakarta Provincial Government. As a priority program for the DKI Jakarta Provincial Government, the down payment should not only be bailed out but also paid/subsidized by the DKI Jakarta Provincial Government so that the selling price of a zero Rupiah down payment house is more affordable for the public. Limited land is an obstacle in making a zero Rupiah down payment house, therefore the DKI Jakarta Provincial Government and BUMD must collaborate in recording regional asset in order that Zero Rupiah downpayment houses exist in every area of DKI Jakarta, such as West, North and South Jakarta. Then in terms of building a house with a zerodown payment, the Rupiah is very feasible, but there must be improvements such as the addition of playing facilities for children and educational facilities for children.

Therefore, there are still many things that must be considered by the DKI Jakarta Provincial Government in implementing the zero Rupiah down payment program in terms of adequate facilities and infrastructure, as according to Jimbro (2010) housing must also be provided with facilities such as educational facilities, health, worship, shopping, recreation, and others that cannot be separated from people's lives. Budiharjo (1993) states that what is often neglected even though it is very important for the feasibility of human life living in the residential environment is the facilities and infrastructure, which include:

a. Social services, such as school, clinics, health centers, hospitals which are generally provided by the government.

b. Social facilities, such as places of worship, funerals, meeting halls, sports fields, playgrounds/open spaces, shops, markets, stalls, street vendors and so on.

c. Environment infrastructure. It includes roads and bridges, clean water, electricity network, telephone network, dirty water network and solid waste.

\section{CONCLUSION}

Based on the description of the results of the research and discussion that has been described in the previous chapter, the writing of this thesis can be concluded regarding the formulation of the zero Rupiah down payment program policy as follows: First. There are many factors that make it difficult for low-income people to own a house in DKI Jakarta, including the increasingly limited land to be used as a place to live so that the longer the land price increases, which results in a backlog of home ownership. This is what makes the DKI Jakarta Provincial Government issue a zero rupiah down payment house program to overcome the problem of the backlog of home ownership in DKI Jakarta. Second. The goal of the zero-rupiah DP house program is to overcome the problem of ownership houses for low-income people who cannot afford a down payment. Third. The zero rupiah down payment program is intended for people who have a steady income and have the ability to pay installments but cannot afford a down payment. Therefore, efforts must be made to improve the community's economy. Fourth. In terms of the registration procedure for the zero rupiah down payment program through the housing office and Bank DKI. If the registrant's file is complete, then check the bank to ensure the ability of the prospective creditor to be able to pay the installments. There are three aspects that affect the zero rupiah down payment program, namely: (a) the political aspect, as the governor's political promise, the zero rupiah down payment house program has become a priority program for the DKI Jakarta 
provincial government. (b) the economic aspect, with a large budget but the money will be returned through creditor installments so that it does not burden the APBD every year in terms of maintenance. (c) legal aspects, Governor's regulation number 104 of 2018 as the basis for implementing the zero rupiah down payment house program. Fifth. The income limit of low-income people in DKI Jakarta follows the regulation of the minister of housing. Sixth. Limited land is an obstacle in making a house with a zero down payment. Then in terms of buildings with zero rupiah down payment, it is very feasible, but there must be improvements such as the addition of playing facilities for children and educational facilities for children.

Due to the limited land area in DKI Jakarta, housing is built in a vertical form because it is cheaper and can accommodate more people. Third. The zero rupiah down payment program is intended for people who have a steady income and are able to pay installments but cannot afford a down payment. Therefore, efforts must be made to improve the community's economy. Fourth. In terms of the registration procedure for the zero rupiah down payment program through the housing office and Bank DKI. If the registrant's file is complete, then check the bank to ensure the ability of the prospective creditor to be able to pay the installments. There are three aspects that affect the zero rupiah down payment program, namely: (a) the political aspect, as the governor's political promise, the zero rupiah down payment house program has become a priority program for the DKI Jakarta provincial government. (b) the economic aspect, with a large budget but the money will be returned through creditor installments so that it does not burden the APBD every year in terms of maintenance. (c) legal aspects, Governor's regulation number 104 of 2018 as the basis for implementing the zero rupiah down payment house program. Fifth. The income limit of low-income people in DKI Jakarta follows the regulation of the minister of housing. Sixth. Limited land is an obstacle in making a house with a zero down payment. Then in terms of buildings with zero rupiah down payment, it is very feasible, but there must be improvements such as the addition of playing facilities for children and educational facilities for children.

\section{REFERENCES}

AR, Mustopadidjaja. (2003). Manajemen Proses Kebijakan Publik Formulasi, Implementasi, dan Evaluasi Kerja. Jakarta: Duta Pertiwi Foundation.

Arum Novia W. Astuti, W. \& Galeng Y. (2011). Efektifitas Program Kredit Perumahan Rakyat (KPR) Bersubsidi Dalam Penyediaan Hunian Bagi Masyarakat Berpenghasilan Rendah Di Perumahan Bumi Rejo Damai Pekalongan. Jurnal Region. Vol. 4, No.1.Jurusan Arsitektur Fakultas Teknik. Universitas Sebelas Maret. Surakarta

Budiharjo, Eko. (1993). Kota Berwawasan Lingkungan. Bandung: Alumni

Creswell, W John \& J. David Creswell (2018). Research Design Qualitative, Quantitative, and Mixed Methods Approach. $5^{\text {th }}$ Edition. Thousand Oaks, United State, Sage Publications.

Dunn, W.N. (2000). Pengantar Analisis Kebijakan Publik (Ed. Ke-2). (Samodra Wibawa, Diah Asitadani, Erwan Agus Purwanto). Yogyakarta: Gajahmada University Press.

Edi, Wibowo. (2004). Hukum dan Kebijakan Publik. Yogyakarta: Yayasan Pembaruan Administrasi Publik Indonesia.

Frick, Heinz dan Mulyani, Tri Hesti. 2006. Arsitektur Ekologis; Konsep Arsitektur Ekologis di Iklim Tropis, Penghijauan Kota dan Kota Ekologis dan Serta energi Terbarukan, Seri Eko-Arsitektur 2. Yogyakarta: Kanisius.

Mangeswuri, Dewi Restu. (2016). Kebijakan Pembiayaan Perumahan Melalui 
Fasilitas Likuidasi Pembiayaan Perumahan (FLPP). Jurnal Ekonomi dan Kebijakan Publik, 7(1), 83-95. http://dx.doi.org/10.22212/jekp.v7i1 .410

Masitoh, Lisa. (2003). Pengaruh Keberadaan Perumahan Terhadap Perubahan HargaLahan di Kecamatan Ciledug, Tugas Akhir, Jurusan Perencanaan
Wilayah Dan Kota, Fakultas Teknik Universitas Diponegoro.

Neuman, W. Lawrence. (2006). Social Research Methods: Qualitative and Quantitative Approaches. Sixth Edition. Boston: Pearson Education, Inc.

Panudju, Bambang. (1999). Pengadaan Perumahan Kota dengan Peran Serta Masyarakat Berpenghasilan Rendah. Bandung: Alumni. 